УДК 616.14-008.64-089.168

DOI 10.11603/2414-4533.2021.3.12547

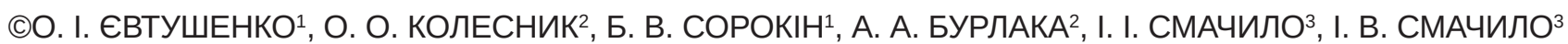

Національний університет охорони здоров'я України імені П. Л. Шупика ${ }^{1}$

Національний Інститут раку²

Тернопільський національний медичний університет імені І. Я. Горбачевського МОЗ $^{3}$

\title{
Особливості перебігу та аналіз післяопераційних ускладнень у хворих на рак ободової кишки
}

\begin{abstract}
Мета роботи: покращити результати хірургічного лікування пацієнтів із раком ободової кишки мінімізувавши ускладнення в післяопераційному періоді.

Матеріали і методи. Оцінено результати лікування 609 хворих, яким у клініці Національного Інститут раку провели радикальні операційні втручання на ободовій кишці з приводу наявного пухлинного процесу. У 92 (15,4 \%) мали місце післяопераційні ускладнення. Померло 37 (6,1 \%) хворих.

Результати досліджень та їх обговорення. Однаково часто ускладнення виникали як у чоловіків, так і у жінок, але значно частіше у хворих похилого та старечого віку (70,9%) та з локалізацією пухлини в лівій половині ободової кишки (67,1 \%). Лише у третини хворих мало місце одне ускладнення, в інших - по два або декілька. Гнійно-запальні ускладнення виникали у 64 (10,1%) хворих, вони домінували в структурі післяопераційних ускладнень і склали 69,7 \%. Найнебезпечнішим був перитоніт, який виник у 15 хворих, із них 9 померли. До найтяжчих ускладнень необхідно віднести розходження швів анастомозу, серцево-судинну недостатність, шлунково-кишкові кровотечі, тромбоемболію легеневої артерії, непрохідність. Значна частина з них стала причиною смерті після успішно виконаного радикального хірургічного втручання. Для запобігання та лікування ускладнень на всіх етапах стаціонарного лікування ми успішно використовували комплекс заходів, які передбачали ретельну передопераційну підготовку з максимально можливою корекцією порушень різних функціональних систем, ретельну підготовку товстої кишки перед операцією за допомогою послаблювальних засобів та клізм, суворого дотримання правил асептики та антисептики на всіх етапах операції, ретельну техніку операційного втручання з дотриманням принципів футлярності, активне ведення післяопераційної рани, застосування антибіотиків широкого спектра дії з попереднім визначенням чутливості мікрофлори, використання різних методів ізоляції органів черевної порожнини для профілактики гнійних ускладнень. Під час операції ретельно, на всіх етапах, виконували гемостаз. Мобілізований препарат видаляли з використанням зшивальних апаратів. Зшивальні апарати також використовували при формуванні анастомозів між дистальною та проксимальною куксами ободової кишки. Ретельно відновлювалася цілісність очеревини. Після операції забезпечувався достатній відтік із черевної порожнини ранової рідини. Рану зрошували розчинами антисептиків. Хворим забезпечували повноцінне парентеральне харчування. Найчастіше гнійно-запальні ускладнення виникали у хворих після операції Гартмана. Ї̈̈ виконували, як правило, хворим похилого та старечого віку або як перший етап лікування раку дистального відділу сигмоподібної кишки при явищах непрохідності.
\end{abstract}

Ключові слова: рак ободової кишки; ускладнення; лікування.

Постановка проблеми і аналіз останніх досліджень та публікацій. Хірургічне лікування раку ободової кишки є основним радикальним методом, який дає змогу сподіватися на стійке і тривале одужання хворих.

Вперше вдалу операцію на ободовій кишці виконав у 1833 р. Рейбард. Йому вдалося резектувати сигмоподібну кишку з приводу ураження злоякісною пухлиною. Хвора через 1,5 року померла від рецидиву захворювання. На жаль, операції на ободовій кишці, в той час, не набули широкого поширення. Провідним стримувальним фактором була недопустимо висока післяопераційна смертність, що досягала $80 \%$.

Результати лікування вдалося 3 часом покращити завдяки розробці і широкому впровадженню багатоетапних хірургічних втручань за методиками Гейнеке (1886), Поля (1891), Блоха (1892), Микуліча (1898). Незважаючи на очевидні недоліки багатомоментних операцій післяопераційну смертність вдалося знизити до 14-16 \% [2].
Сучасна хірургія ободової кишки передбачає одномоментні операційні втручання, при лікуванні неускладнених форм раку цієї локалізації.

Незважаючи на значне покращання якості діагностики, значна частина хворих на РОК надходить у клініку з розповсюдженими формами захворювання, а більш як одна третина - інкурабельні. Наведені факти суттєво обмежують показники як операбельності, так і резектабельності. За даними різних авторів $[1,8]$, показник резектабельності знаходиться в межах від 34 до 82 \%. Таку велику різницю пояснює низка обставин, але найчастіше залежить від суб'єктивної оцінки оперуючого хірурга.

Окрім того, у 2/3 хворих на рак ободової кишки (POK) до початку лікування мають місце серйозні супутні ураження життєво важливих органів і систем: серцево-судинної (у 37 \% хворих), легеневої (у 27 \%), гіпертонічна хвороба (у $19 \%$ ), цукровий діабет (у $10 \%$ ) та ін. Це пов'язано, головним чином, з відносно похилим віком хворих на рак РТК 


\section{З ДОСВІДУ РОБОТИ}

- пік захворюваності припадає на осіб, старших 60 років [3, 5, 6].

Аналіз результатів хірургічного лікування POK, як свідчать сучасні публікації, вказує на стабілізацію показників безпосереднього, найближчого та віддаленого виживання, оскільки суттєвих відмінностей від показників 10-20-річної давності не спостерігається [6].

Рак ободової кишки, який є одним із найбільш поширених уражень, має високі темпи зростання та займає п’яту позицію в загальній структурі онкозахворювань [7]. Як було зазначено, хірургічне лікування хворих на РОК, лишається основним методом, що дає надію на тривале та стійке одужання. Завдяки успіхам в анестезіології та реаніматології та техніці виконання операцій значно розширені показання до радикальних хірургічних втручань у хворих із розповсюдженими формами раку та у хворих старечого віку. Водночас спостерігаються відносно високі показники післяопераційних ускладнень, зумовлені значною травматичністю та великим об'ємом операцій, розповсюдженістю ракового процесу, при якому виконується більшість операцій, виконанням певних етапів в умовах відкритого просвіту ободової кишки, що зумовлює ризик інфікування операційної рани та черевної порожнини в цілому. За даними багатьох дослідників, частота післяопераційних ускладнень складає від 20 до 60 \% [1, 4], насамперед за рахунок ускладнень гнійно-запального характеру.
Мета роботи: покращити результати хірургічного лікування пацієнтів із раком ободової кишки мінімізувавши ускладнення в післяопераційному періоді.

Матеріали і методи. В клініці Національного Інститут раку за 15-річний період з 609 радикально прооперованих хворих на РОК у 92 (15,4 \%) мали місце післяопераційні ускладнення. Померло 37 (6,1 \%) хворих. Виконували стандартні радикальні операції прийняті для лікування раку ободової кишки залежно від локалізації пухлини. Загальна характеристика хворих наведена в таблиці 1.

Результати досліджень та їх обговорення. Однаково часто ускладнення виникали як у чоловіків, так і в жінок, але значно частіше у хворих похилого та старечого віку (70,9 \%) та 3 локалізацією пухлини в лівій половині ободової кишки (67,1\%).

Лише у третини хворих мало місце одне ускладнення, в інших - по два або декілька. Характер післяопераційних ускладнень наведено в таблиці 2.

Гнійно-запальні ускладнення виникали у 64 (10,1 \%) хворих, вони домінували в структурі післяопераційних ускладнень і склали 69,7%. Найбільш небезпечнім із них був перитоніт, який виник у 15 хворих, із них 9 померли. До найбільш тяжких ускладнень необхідно віднести розходження

Таблиця 1. Загальна характеристика хворих на рак ободової кишки з післяопераційними ускладненнями

\begin{tabular}{||l|c||}
\hline \multicolumn{1}{|c|}{ Назва показника } & Кількість \\
\hline Всього хворих & 92 \\
\hline Стать: & \\
чоловіки & \\
жінки & $44(48,2 \%)$ \\
\hline Вік: & $48(51,8 \%)$ \\
$\quad$ до 40 років & \\
$40-49$ & $4(4,3 \%)$ \\
$50-59$ & $10(9,9 \%)$ \\
$60-69$ & $14(14,9 \%)$ \\
70 та старші & $47(51,3 \%)$ \\
\hline Стадія: & $17(19,6 \%)$ \\
$2\left(\mathrm{~T}_{3-4} \mathrm{~N}_{0}\right)$ & $68(75,4 \%)$ \\
3 (т2-4 $\left._{1}\right)$ & $24(24,6 \%)$ \\
\hline Локалізація: & \\
Ліва половина & $62(67,1 \%)$ \\
Права половина & $31(32,9 \%)$ \\
\hline \hline
\end{tabular}


Таблиця 2. Характер післяопераційних ускладнень

\begin{tabular}{|c|c|c|}
\hline Ускладнення & Кількість & Із них померли \\
\hline $\begin{array}{l}\text { Гнійно-запальні: } \\
\text { Нагноєння післяопераційної рани } \\
\text { Перитоніт } \\
\text { Абсцес черевної порожнини, таза } \\
\text { Пневмонії }\end{array}$ & $\begin{array}{c}41 \\
15 \\
3 \\
5\end{array}$ & $\begin{array}{l}- \\
8 \\
2 \\
3\end{array}$ \\
\hline Розходження швів анастомозу & 5 & 3 \\
\hline Непрохідність & 4 & 3 \\
\hline Евентерація & 2 & - \\
\hline Шлунково-кишкові кровотечі & 7 & 5 \\
\hline $\begin{array}{l}\text { Серцево-судинні ускладнення (інфаркт, } \\
\text { серцево-судинна недостатність) }\end{array}$ & 6 & 5 \\
\hline Тромбоемболія легеневої артерії & 4 & 4 \\
\hline Всього & 92 & 33 \\
\hline
\end{tabular}

швів анастомозу, серцево-судинну недостатність, шлунково-кишкові кровотечі, тромбоемболію легеневої артерії, непрохідність. Значна частина 3 них стала причиною смерті після успішно виконаного радикального хірургічного втручання.

Причини післяопераційних гнійно-запальних ускладнень доволі різноманітні. Серед багатьох факторів, які сприяють їх виникненню в ранньому післяопераційному періоді, важливе значення має загальній стан хворого, його біологічний вік, характер і тяжкість супутніх захворювань, стан імунологічної резистентності організму, а також розповсюдженість процесу. До провідних факторів виникнення гнійних ускладнень необхідно віднести автофлору хворого, яка може набувати патогенних властивостей при зниженні резистентності організму як в процесі розвитку пухлини, так і в ослаблених хворих у післяопераційному періоді. Причиною їх також можуть бути технічні погрішності в процесі хірургічного втручання, які призводять до інфікування.

Привертає увагу згладженість та атипічність клінічних проявів перитоніту, а в значній частині випадків їх повна відсутність, при цьому суттєво ускладнювалась рання діагностика того чи іншого ускладнення. Симптоми, що спостерігались, можна було інтерпретувати як ознаки дихальної, серцево-судинної, нирково-печінкової недостатності. Провідним симптомом у всіх випадках був стійкий парез кишечника, що не піддавався лікуванню, а також наростання синдрому ендогенної інтоксикації, незважаючи на інтенсивну детоксикаційну терапію. Класичні прояви перитоніту такі, як сильний біль у животі, напруження м’язів передньої черевної стінки, позитивний симптом Щоткіна - Блюмберга спостерігались рідко. Згладженість клінічних проявів перитоніту та їх бідність пояснюється зниженням як загальної, так і місцевої резистентності організму. Цим хворим тривалий час проводять консервативну терапію та операційне втручання виконується, не рідко, з запізненням.

Для запобігання та лікування ускладнень на всіх етапах стаціонарного лікування ми успішно застосовували комплекс заходів, які передбачали ретельну передопераційну підготовку 3 максимально можливою корекцією порушень різних функціональних систем, ретельну підготовку товстої кишки перед операцією за допомогою послаблювальних засобів та клізм, суворого дотримання правил асептики та антисептики на всіх етапах операції, ретельну техніку операційного втручання 3 дотриманням принципів футлярності, активне ведення післяопераційної рани, застосування антибіотиків широкого спектра дії 3 попереднім визначенням чутливості мікрофлори, використання різних методів ізоляції органів черевної порожнини для профілактики гнійних ускладнень (Лисецький В. А. та співавтори, 1988). Перед операцією проводили ретельну підготовку товстої кишки, санітарно-гігієнічну обробку шкіри передньої черевної стінки. Під час операції ретельно, на всіх етапах, виконували гемостаз. Мобілізований препарат видаляли з використанням зшивальних апаратів. Зшивальні апарати також 


\section{З ДОСВІДУ РОБОТИ}

використовували при накладанні анастомозів між дистальною та проксимальною куксами ободової кишки. Ретельно відновлювалась цілісність очеревини. Після операції забезпечували достатній відтік із черевної порожнини ранової рідини. Рану зрошували розчинами антисептиків. Суворо дотримувались правил асептики та антисептики під час перев’язок. Хворим забезпечували повноцінне парентеральне харчування. Проводили антибіотикотерапію, гемостимулювальну та загальнозміцнювальну терапію. Найчастіше гнійно-запальні

\section{СПИСОК ЛІТЕРАТУРИ}

1. Власов А. В. Ближайшие и отдаленные результаты лечения рака толстой кишки / А. В. Власов // Хирургия. - 1999. - № 2. - С. 51-52.

2. Ганичкин А. М. Рак толстой кишки / А. М. Ганичкин. Москва : Медицина, 1970. - С. 415.

3. Євтушенко О. I. Профілактика післяопераційних гнійно-запальних ускладнень у хворих на рак ободової кишки / О. І. Євтушенко, Д. В. Мясоєдов // Шпитальна хірургія. - 1999. - № 9. - С. 22-23.

4. Євтушенко О. І. Шляхи підвищення ефективності хірургічного лікування хворих на рак ободової кишки / О. І. Євтушенко, Б. В Сорокін., О. О. Колесник // Клінічна хірургія. 2000. - № 12. - C. 29-30.

\section{REFERENCES}

1. Vlasov, A.V. (1999). Blizhayshie i otdalennye rezultaty lecheniya raka tolstoy kishki [Immediate and long-term results of colon cancer treatment]. Hirurgiya - Surgery, 2, 51-52 [in Russian].

2. Ganichkin, A.M. (1970). Rak tolstoy kishki [Colon cancer]. Moscow: Meditsina [in Russian].

3. Evtushenko, O.I., \& Myasoedov, D.V. (1999). Profilaktyka pisliaoperatsiinykh hniino-zapalnykh uskladnen u hvorykh na rak obodovoi kyshky [Prevention of postoperative purulent-inflammatory complications in patients with colon cancer]. Shpytalna khirurhiia - Hospital Surgery, 9, 22-23 [in Ukrainian].

4. Evtushenko, O.I., Sorokin, B.V., \& Kolesnik, O.O. (2000). Shliakhy pidvyshchennia efektyvnosti khirurhichnoho likuvannia khvorykh na rak obodovoi kyshky [Ways to increase the effectiveness of surgical treatment of patients with colon cancer]. Klinich- ускладнення виникали у хворих після операції Гартмана. Її виконували, як правило, хворим похилого та старечого віку або як перший етап лікування раку дистального відділу сигмоподібної кишки при явищах непрохідності.

Висновки. Застосування індивідуального підходу до кожного пацієнта в доопераційний та післяопераційний період дало змогу зменшити частоту післяопераційних ускладнень у хворих на рак ободової кишки.

5. Шалімов С. О. Сучасна діагностика і лікування злоякісних пухлин ободової кишки / С. О. Шалімов, О. І. Євтушенко, Д. В. Мясоєдов. - Київ : Четверта хвиля, 2004. - С. 248.

6. Комбіноване лікування хворих на рак ободової кишки / Шалімов С. О., Євтушенко О. І., Мясоєдов Д. В., Приймак В. В. - Київ : Четверта хвиля, 2006. - С.166.

7. Федоронко 3. П. Рак в Україні 2018-2019 / 3. П. Федоронко // Бюлетень Національного канцер-реєстру. - 2020. - № 21.C. 145.

8. Williams N. S. Surveillans and early diagnosis of colorectal cancer / N. S. Williams, P. Prorok // Eur. J. Surg. Oncol. - 1996. Vol. 224, No. 6. - P. 592-597.

na khirurhiia - Clinical Surgery, 12, 29-30 [in Ukrainian]. 5. Shalimov, S.O., Evtushenko, O.I., \& Myasoedov, D.V. (2004). Suchasna diahnostyka i likuvannia zloiakisnykh pukhlyn obodovoi kyshky [Modern diagnosis and treatment of malignant tumors of the colon]. Kyiv: Chetverta hvylia [in Ukrainian]. 6. Shalimov, S.O., Evtushenko, O.I., Myasoedov, D.V., \& Priymak, V.V. (2006). Kombinovane likuvannia khvoryh na rak obodovoi kyshky [Combined treatment of patients with colon cancer]. Kyiv: Chetverta khvylia [in Ukrainian].

7. Fedoronko, Z.P. (2020). Rak v Ukraini 2018-2019 [Cancer in Ukraine 2018-2019]. Biuleten Natsionalnoho kantser-reiestru Bulletin of the National Cancer Registry, 21, 145 [in Ukrainian]. 8. Williams, N.S., \& Prorok, P. (1996). Surveillans and early diagnosis of colorectal cancer. Eur. J. Surg. Oncol., 224, 6, 592-597.

Отримано 02.08.2021 
Shupyk National Medical Academy of Post-Graduate Education ${ }^{1}$

National Cancer Institute ${ }^{2}$

I. Horbachevsky Ternopil National Medical University ${ }^{3}$

\section{PECULIARITIES OF POSTOPERATIVE COMPLICATIONS COURSE AND ANALYSIS IN PATIENTS WITH COLON CANCER}

The aim of the work: to improve the results of surgical treatment of patients with colon cancer by minimizing of postoperative complications period.

Materials and Methods. There were evaluated the results of treatment of 609 patients who had undergone radical surgery on the colon due to the tumor process existing in the clinic of the National Cancer Institute. Postoperative complications occurred in 92 (15.4 \%) patients. 37 (6.1\%) patients died.

Results and Discussion. Complications are equally common occurred in both men and women, but much more often in elderly and senile age patients (70.9\%) and with localization of the tumor in the left half of the colon (67.1\%). Only one third of patients had one complication, others had two or more complications. Purulent-inflammatory complications occurred in 64 (10.1\%) patients, they dominated in the structure of postoperative complications $(69.7 \%)$. The most dangerous of these was peritonitis, which occurred in 15 patients, 9 of them died. The most serious complications include differences in anastomotic sutures, cardiovascular insufficiency, gastrointestinal intestinal bleeding, pulmonary embolism, obstruction. Significantly some of them were the cause of death after successful completion radical surgery. For prevention and treatment complications at all stages of inpatient treatment we successfully used a set of measures which provided careful preoperative preparation with the maximum possible correction of different functional systems violations, careful preparation of the colon before surgery with laxatives and enemas, severe compliance with the asepsis and antiseptics rules at all stages of the operation, careful technique of surgical intervention in compliance with the principles of case, active postoperative wound management, the use of broad-spectrum antibiotics with preliminary determination of microflora sensitivity, the use of various methods of isolation of the abdominal organs cavities for the prevention of purulent complications. Hemostasis was carefully performed during all stages of the operation. The mobilized preparation was removed by using stapling devices. Stitching machines were also used in the imposition of anastomoses between the distal and proximal colon stumps. Peritoneal integrity was carefully restored. After the operation, a sufficient outflow of wound fluid from abdominal cavity was provided. The wound was irrigated with solutions antiseptics. Patients were provided with full parenteral food. Purulent-inflammatory complications most often occurred in patients after Hartmann's operation. It was performed, as a rule, to elderly and senile age patients or as the first stage of treatment of distal sigmoid colon cancer at intestinal obstruction.

Key words: colon cancer; complications; treatment. 